J. Clin. Chem. Clin. Biochem.

Vol. 16, 1978, pp. 127-134

\title{
Thin Layer Chromatographic Screening for Methaqualone, Phenothiazines, Opiates and Benzodiazepines
}

\author{
By J. Breiter, R. Helger
}

Biochemische Forschung E. Merck, Darmstadt, Germany,

E. Interschick and $H$. Wüst

Medizinisch-Diagnostisches Institut, Städtische Krankenanstalten, Karlsruhe, Germany

(Received August 6, 1976/August 10, 1977)

Summary: A method is described which permits the simultaneous detection of methaqualone, phenothiazines, opiates and benzodiazepines in urine. Its diagnostic application is discussed. After cleavage of conjugates with hydrochloric acid, the substances are extracted and identified by thin-layer chromatography. In most cases analysis can be carried out using 2 solvent systems, phenothiazines, methaqualone and opiates being visualised using a three stage spray sequence. Since phenothiazines can interfere with the detection of methaqualone, a specific eluant is used to ensure reliable detection of the latter. Methaqualone can be positively identified by its characteristic metabolite pattern, whereas phenothiazines can only be detected as a group.

\section{Dünnschichtchromatographische Nachweismethode für Methaqualon, Phenothiazine, Opiate und Benzodiazepine}

Zusammenfassung: Eine Methode zum gleichzeitigen Nachweis von Methaqualon, Phenothiazinen, Opiaten und Benzodiazepinen im Harn wird beschrieben und deren diagnostische Anwendung diskutiert. Nach Spaltung der Konjugate werden die Substanzen extrahiert und durch Dünnschichtchromatographie nachgewiesen. Dafür genügen meistens 2 Laufmittelsysteme, eines für Benzodiazepine, ein anderes für Phenothiazine, Methaqualon und Opiate. Da Phenothiazine den Nachweis von Methaqualon stören, kann dieser durch ein spezifisches Laufmittel gesichert werden. Methaqualon kann durch charakteristische Metaboliten-Muster eindeutig, Phenothiazine können nur als Gruppe erkannt werden.

\section{Introduction}

Many screening tests for hypnotics and addictive drugs involve checking only for unconjugated metabolites excreted in the urine. Substances are concentrated by liquid-liquid extraction (1), the use of ion-exchange paper (2) or non-ionic resin adsorption columns $(3,4)$. They may often fail in the detection of important compounds such as morphine, codeine, phenothiazines, benzodiazepines and methaqualone, as these are excreted partly in metabolized form and partly as conjugates with glucuronic and sulfuric acid $(5,6,7,8)$. The detection of the individual compounds by thin-layer chromatography (TLC) using different specially suited solvents following hydrolysis of the urine sample is well described in the literature; but there is a lack of comprehensive systems for the determination of all the conjugated substances together. The various systems often do not fit into a general screening programme, as they are designed to give the best results for the detection of special compounds, or the detection is subject to interference by other compounds. For instance, ether is very suitable for the detection of methaqualone metabolites $(9,10)$, but does not detect morphine and codeine; ethyl acetate/ methanol/ammonia (volumes, $85 \mathrm{ml}+10 \mathrm{ml}+5 \mathrm{ml}$ ) (11) yields good results for methaqualone and morphine, but is of little use, if phenothiazines are present.

We set up a screening method for free and conjugated compounds in urine, which involves extraction at an acid and alkaline $\mathrm{pH}$, hydrolysis of an additional amount of the sample, extraction and TLC separation of the drugs $(12,13)$. In the present paper the detection of drugs following hydrolysis of the urine is considered.

The conjugated substances, except benzodiazepines, are detected by the same two solvent systems as are used for the detection of the hypnotics and sedatives. Special 
attention has been paid to the detection of methaqualone, as this substance is frequently encountered in cases of intoxication by hypnotics. Reports relating to the determination of this substance in body fluids without prior hydrolysis are contradictory, even in cases of overdosage $(9,10,11,14,15)$.

The detection by TLC without prior hydrolysis was therefore also tried. It is the aim of this work to demonstrate that hydrolysis of urines is not only advantageous but essential for some of the drugs reported above.

\section{Materials and Methods}

Unless otherwise stated, analytical-grade solvents and reagents were from E. Merck, Darmstadt, Germany.

Chromatography was performed on precoated TLC plates Silica gel $60 \mathrm{~F}_{254}, 20 \times 20 \mathrm{~cm}$ or $10 \times 20 \mathrm{~cm}$ Merck, No. 5715 or 5729.

Substances were applied to the plates with the aid of $5 \mu \mathrm{l}$ capillary dosing pipettes (Link, Wertheim, Germany); spots were visualised using a "Spray Gun" (Desaga, Heidelberg, Germany).

\section{Spray reagents}

\section{Nitrite reagent}

Dissolve $1 \mathrm{~g}$ of $\mathrm{NaNO}_{2}$ in $90 \mathrm{ml}$ of water (this solution being stable indefinitely), and add $2 \mathrm{ml}$ of $7 \mathrm{~mol} / 1 \mathrm{HCl}$ (must be used within 1 hour).

\section{Coupling reagent}

$14 \mathrm{mmol} / \mathrm{l} \mathrm{N}$-(1-naphthyl)ethylenediammonium dichloride in methanol.

\section{Potassium iodoplatinate}

Mix $1.0 \mathrm{ml}$ of $0.2 \mathrm{~mol} / 1$ hexachloroplatinic acid solution with $20 \mathrm{ml}$ of $0.6 \mathrm{~mol} / 1 \mathrm{KI}$ solution and $40 \mathrm{ml}$ of water.

\section{Dragendorff's reagent (16)}

Stock solution: Dissolve $1.7 \mathrm{~g}$ of basic bismuth nitrate and $20 \mathrm{~g}$ of tartaric acid in $80 \mathrm{ml}$ of water; dissolve $16 \mathrm{~g}$ of potassium iodide in $40 \mathrm{ml}$ of water; mix equal volumes of these two solutions (stable for several months when stored in a refrigerator).

Spray solution: Mix 1 part of stock solution with 10 parts by volume of $1.33 \mathrm{~mol} / \mathrm{l}$ aqueous tartaric acid solution.

\section{Hydrolysis of conjugated substances and extraction}

Reflux $10 \mathrm{ml}$ of urine with $10 \mathrm{ml}$ of $7 \mathrm{~mol} / 1$ hydrochloric acid for 15 minutes. Adjust hydrolysate to $\mathrm{pH} 9-9.5$ with $3-4 \mathrm{~g}$ $\mathrm{NaOH}$ and $3 \mathrm{ml}$ saturated ammonium chloride/ammonium hydroxide $(15 \mathrm{~mol} / \mathrm{l}$, minimum $250 \mathrm{~g} / \mathrm{l})$ buffer $\mathrm{pH} 9.5$. Extract with $50 \mathrm{ml}$ dichloromethane/isopropanol (Volumes, $85 \mathrm{ml}+$ $15 \mathrm{ml}$ ). Centrifuge at $3000 \mathrm{rpm}$, draw off and discard the aqueous phase; filter the solvent phase through Whatman 1 PS phase separation paper and reduce under a stream of nitrogen in tapered glass tubes. Dissolve the residue in $50 \mu \mathrm{l}$ of isopropanol.

Thin-layer chromatography, general procedure

Apply 10-15 $\mu$ ldissolved residues (corresponding to $2-3 \mathrm{ml}$ of urine) on a TLC plate in streaks $(1-1.5 \mathrm{~cm})$; apply reference solutions $(10-15 \mu \mathrm{l})$ such that the streaks overlap by about $1 / 3$. Saturate chromatographic chambers lined with filter paper, for 15 minutes with $200 \mathrm{ml}$ solvent. Develop the plates to a distance of $10 \mathrm{~cm}$.

\section{Benzodiazepines}

Develop extract with benzene/acetone (Volumes; $95 \mathrm{ml}+5 \mathrm{ml}$ ). The reference solution is an extract from the hydrolysate of chlorodiazepoxide and nitrazepam. After air drying spray the plate carefully with nitrite reagent and after about 1 minute, with coupling reagent.

Phenothiazines, methaqualone, morphine, codeine

Develop extract in the lower phase from a mixture of chloroform/ ethanol/aqueous ammonium hydroxide $(250 \mathrm{~g} / \mathrm{l})$ (Volumes, $80 \mathrm{ml}+15 \mathrm{ml}+5 \mathrm{ml}$ ). The reference is a $0.5 \mathrm{~g} / 1$ solution of morphine, codeine, methaqualone, levomepromazine and phenacetin in isopropanol. After development dry the plate for 10 minutes at $100^{\circ} \mathrm{C}$. Mark the position of phenacetin under UV light. Spray the plate with $0.76 \mathrm{~mol} / \mathrm{l}(50 \mathrm{~g} / \mathrm{l})$ sulfuric acid until just transparent and blow with warm air using a hair dryer for 5-7 minutes (phenothiazines). Then spray with potassium iodoplatinate until just transparent, and blow for 5 minutes with cold air (methaqualone, phenothiazines, opiates). Then spray the plate until moist with an aqueous solution of equal parts of $2.9 \mathrm{~mol} / 1$ silver nitrate solution and $5 \mathrm{~mol} / \mathrm{l}$ ammonium hydroxide solution, heat for 5 minutes at $100^{\circ} \mathrm{C}$ (morphine).

\section{Methaqualone}

Develop extract and reference solution with chloroform/acetone (Volumes, $80 \mathrm{ml}+20 \mathrm{ml}$ ). Mark phenacetin under UV light and spray the plate with Dragendorff's reagent. Methaqualone metabolites show orange-red spots.

Estimation of concentrations and detection limits by TLC Determine morphine and methaqualone by comparing with TLC of reference solutions of defined concentrations. For methaqualone metabolites identical coloration is anticipated because of very similar chemical constitution with methaqualone. The concentration of benzodiazepine derivates is estimated by comparison with spot intensities obtained after hydrolysis and TLC of defined solutions of chlorodiazepoxide and nitrazepam.

\section{Quantitative determination of methaqualone excretion}

Hydrolyze $10 \mathrm{ml}$ of urine as described, extract twice with $30 \mathrm{ml}$ of ether, dry with anhydrous $\mathrm{Na}_{2} \mathrm{SO}_{4}$. Extract ether phase twice with $10 \mathrm{ml}$ of $0.1 \mathrm{~mol} / 1 \mathrm{HCl}$. Record $\mathrm{HCl}$ phase using a Zeiss DMR 10 double beam spectrophotometer from 200 to $325 \mathrm{~nm}$. Measure absorbance at $235 \mathrm{~nm}\left(\mathrm{~A}_{1 \mathrm{~cm}}^{1 \%}\right.$ for methaqualone $=1350$ ).

\section{Results}

\section{Benzodiazepines}

After hydrolysis with hydrochloric acid, many of the benzodiazepine metabolites (7) yield 5-chloro-2-aminobenzophenone (chlorodiazepoxide group), nitrazepam yields 5-nitro-2-aminobenzophenone (7) $\left(R_{f} 0.44\right.$ and 0.30 in benzene/acetone). Upon visualisation these substances produce blue violet and red violet spots. Aminophenazone metabolites appear as blue spots $\left(R_{f_{\max }} 0.2-0.25\right)$. High concentrations can disturb the detection of traces but not of relevant quantities of nitrazepam. The lower detection limit for benzodiazepines is $25-50 \mu \mathrm{g} / \mathrm{l}$, after spotting $2 \mathrm{ml}$ of urine. $2.5 \mathrm{mg}$ of diazepam could still be detected between 10 and 36 hours after intake as a spot roughly corresponding to $0.5 \mathrm{mg} / \mathrm{l}$ of urine. Three days after discontinuation of $20 \mathrm{mg}$ daily of chlorodiazepoxide, a concentration of about $2 \mathrm{mg} / \mathrm{l}$ of metabolite in urine could be measured. Following overdoses of diazepam (100 mg), chlorodiazepoxide and medazepam the concentration of cleavable and TLC-detectable metabolites was between 8 and $10 \mathrm{mg} / \mathrm{l}$ in the first urine taken from the patients. 
Methaqualone, phenothiazines, morphine, codeine

Morphine and codeine are excreted unchanged and in conjugated form in the urine (5), methaqualone and phenothiazines, on the other hand, being excreted in almost totally metabolised form. All three substance groups are tested for using the solvent system chloroform/ethanol/ammonium hydroxide (Volumes, $80 \mathrm{ml}+$ $15 \mathrm{ml}+5 \mathrm{ml}$ ). Detection is by consecutive spraying with $0.76 \mathrm{~mol} / \mathrm{l}$ sulfuric acid, potassium iodoplatinate and ammoniacal silver nitrate (compare fig. $1 \mathrm{a}, \mathrm{b}, \mathrm{c}$ ).

\section{1 st stage of spray sequence: phenothiazines}

Phenothiazine metabolites produce red, blue and violet spots upon heating with $0.76 \mathrm{~mol} / \mathrm{l}$ sulfuric acid; metabolites of prothipendyl, a similar compound, produce yellow spots, which are also distributed over the whole chromatographic distance (Sample A). Even in cases where the therapeutic dose of $50 \mathrm{mg}$ promethazine per day has been taken, 7 red and violet spots are obtained.
Heating for longer periods intensifies the color of the phenothiazine spots, but reduces the sensitivity of the subsequent methaqualone detection. The excreted products following administration of promazine, perphenazine, promethazine, levomepromazine and prothipendyl were investigated using urines from different patients. Each substance gave a specific, but little characteristic metabolite pattern. The ingested substance could of ten not be detected in the chromatogram (compare 1.c. (6)). Thus it is not possible to draw any conclusion from TLC as to the substance ingested. Only recognition of the presence of substances from the phenothiazine group is possible.

$2 \mathrm{nd}$ and $3 \mathrm{rd}$ stage of the spray sequence (Fig. $1 \mathrm{~b}$ and $1 \mathrm{c})$

Phenothiazine and methaqualone metabolites, morphine and codeine react with potassium iodoplatinate to form spots, the color and location of which are given in table 1 . Upon heating with ammoniacal silver nitrate, morphine

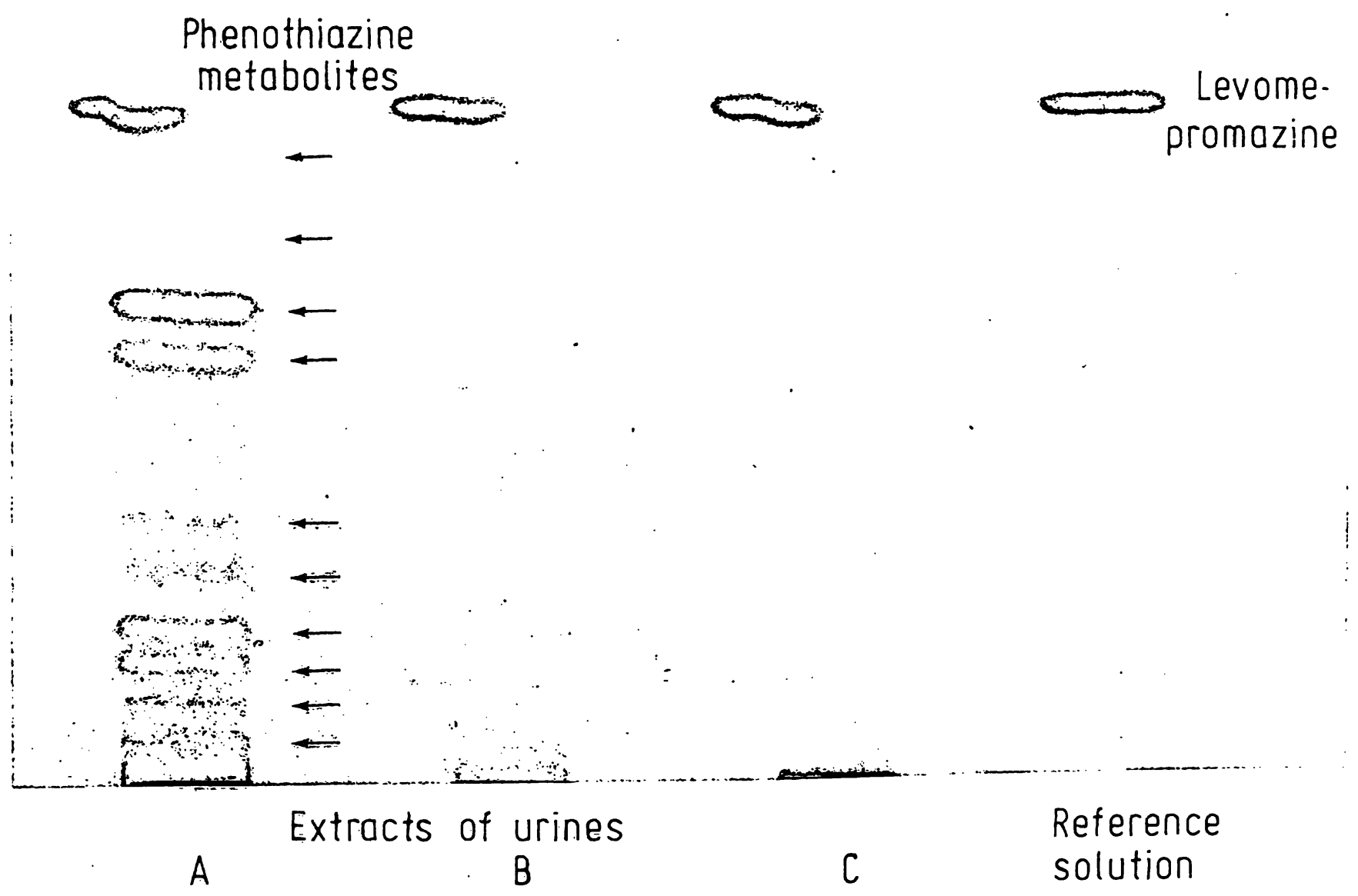

Fig. 1. TLC-screening for drugs in urine. Detection of phenothiazines, methaqualone and morphine on a single plate by consecutive spraying with different reagents. Layer: Precoated TLC-plate silica gel $60 \mathrm{~F}_{254}$. Solvent: Chloroform/ethanol/ammonia (volumes, $80 \mathrm{ml}+15 \mathrm{ml}+5 \mathrm{ml}$ ).

Detection: 1. Sulfuric acid (fig. 1 a),

2. Potassium iodoplatinate (fig. $1 \mathrm{~b}$ ),

3. Ammoniacal silver nitrate (fig. $1 \mathrm{c}$ ).

a) Detection: sulfuric acid

A positive for phenothiazines 


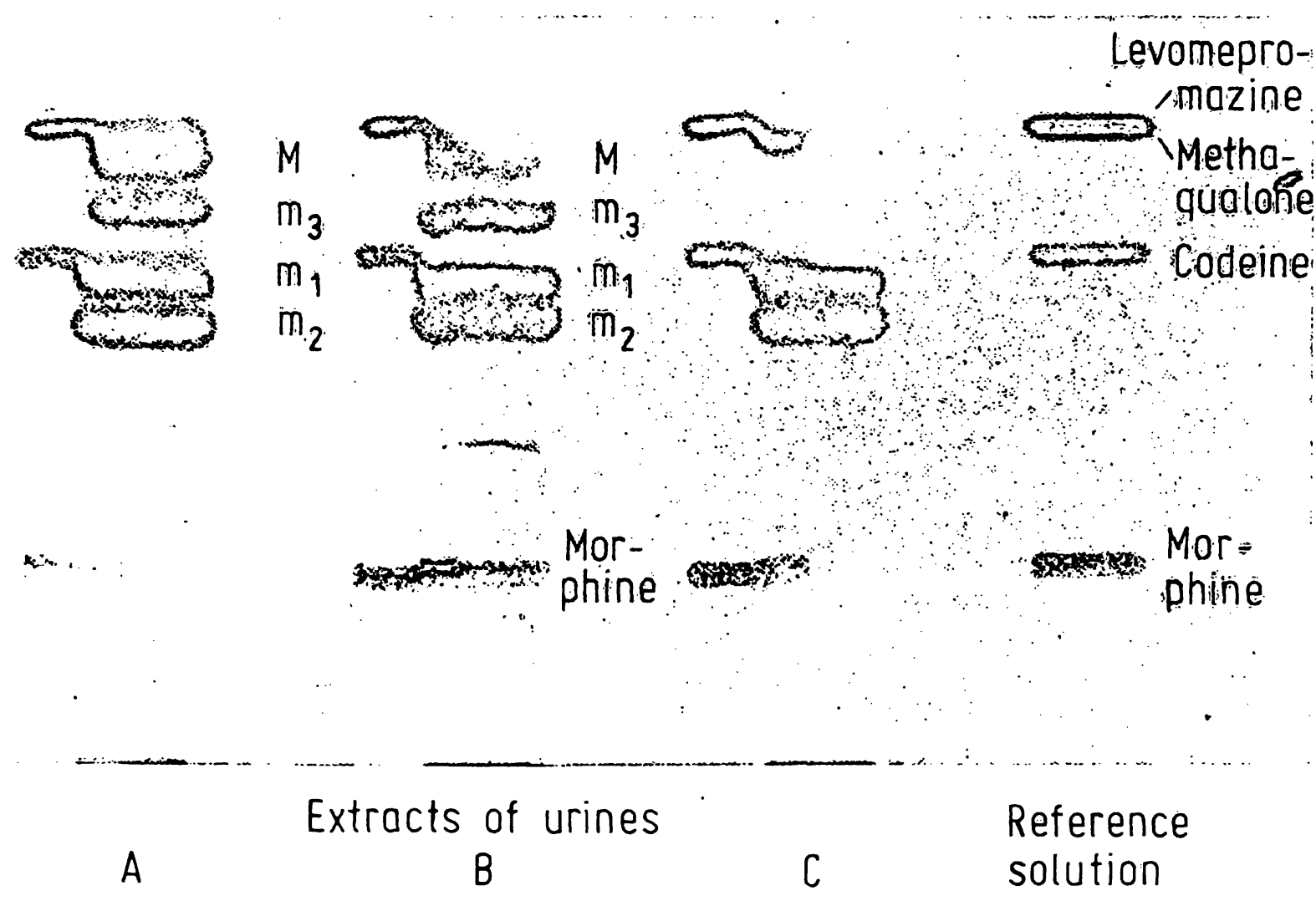

b) Detection: sulfuric acid, potassium iodoplatinate

A 4 methaqualone metabolites, partly overlapped by phenothiazine metabolites

B 4 methaqualone metabolites and morphine

C 2 methaqualone metabolites

Methaqualone in A and B following ingestion of an overdose, in C following a therapeutic dose of $400 \mathrm{mg}$

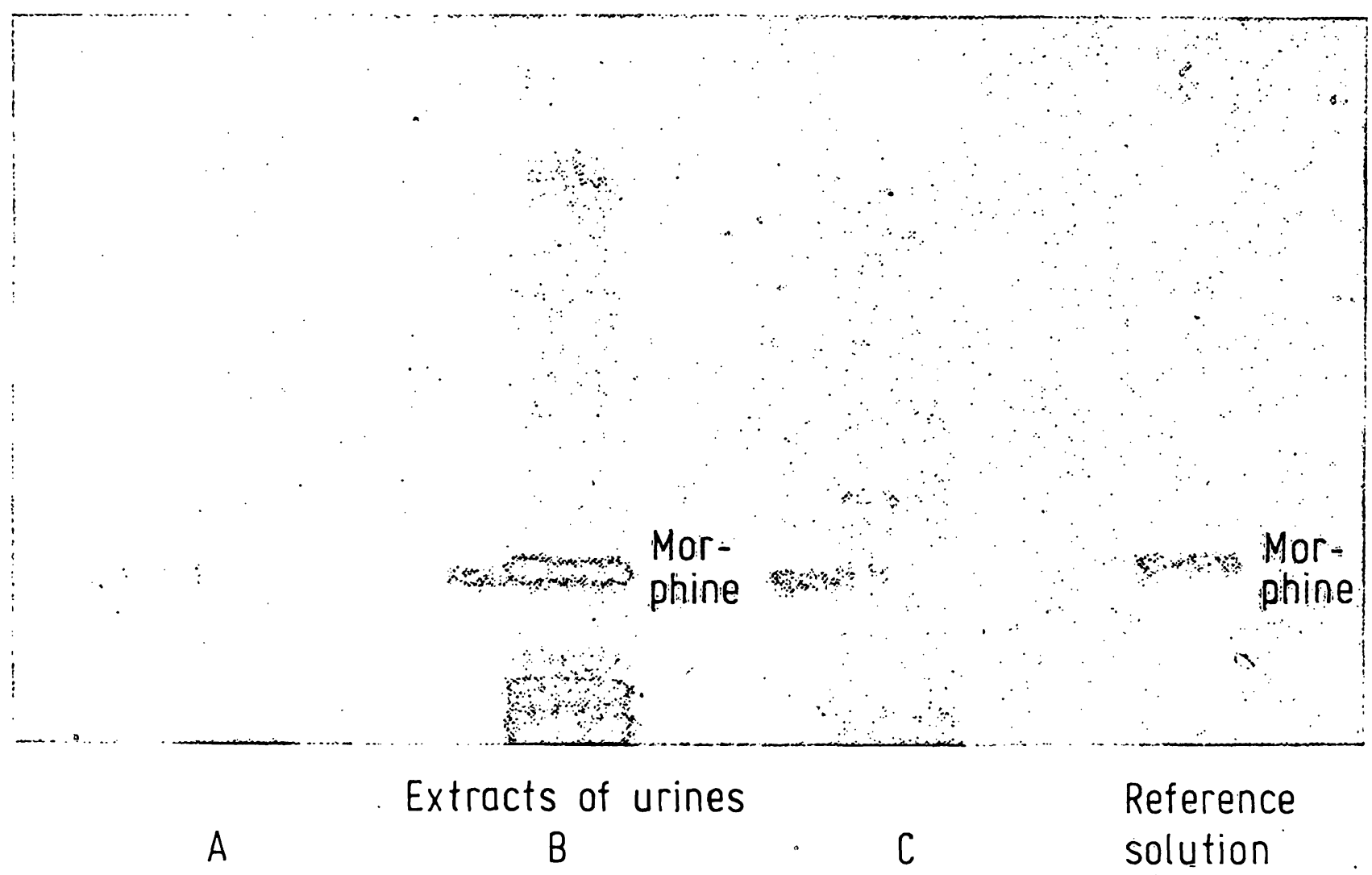

c) Detection: sulfuric acid, potassium iodoplatinate, ammoniacal silver nitrate

B positive for morphine 
Tab. 1. TLC-screening for drugs in urine

$R_{f}$ values and colouration of phenothiazines, methaqualone and opiates

Layer: Precoated TLC-plate silica gel $60 \mathrm{~F}_{254}$ Solvent: Chloroform/ethanol/ammonia $250 \mathrm{~g} / \mathrm{l}$ (Volumes $80 \mathrm{ml}+1.5 \mathrm{ml}+5 \mathrm{ml})$

\begin{tabular}{|c|c|c|c|}
\hline Substance & $R_{\mathbf{f}} \times 100$ & Detection $^{1}$ ) & Colour reaction \\
\hline Levomepromazine & 82 & 1,2 & $\begin{array}{l}\text { blue (1) } \\
\text { dark brown (2) }\end{array}$ \\
\hline Promethazine & 80 & 1,2 & $\begin{array}{l}\text { red }(1) \\
\text { dark brown (2) }\end{array}$ \\
\hline $\begin{array}{l}\text { Nicotine } \\
\text { Nicotine }\end{array}$ & 78 & 2 & blue green \\
\hline $\begin{array}{l}\text { Nicotine } \\
\text { metabolite }\end{array}$ & 42 & 2 & black violet \\
\hline $\begin{array}{l}\text { Ethylmorphine } \\
\text { Codeine } \\
\text { Hydromorphone } \\
\text { Morphine }\end{array}$ & $\begin{array}{l}63 \\
59 \\
31 \\
22\end{array}$ & $\begin{array}{l}2 \\
2 \\
2 \\
2,3\end{array}$ & $\begin{array}{l}\text { grey violet } \\
\text { grey violet } \\
\text { blue violet } \\
\text { blue black (2) } \\
\text { grey black (3) }\end{array}$ \\
\hline \multicolumn{4}{|l|}{$\begin{array}{l}\text { Methaqualone } \\
\text { metabolites }\end{array}$} \\
\hline $\begin{array}{l}\text { M } \\
\mathrm{m}_{3} \\
\mathrm{~m}_{1} \\
\mathrm{~m}_{2} \\
\text { Methaqualone } \mathrm{e}^{2} \text { ) } \\
\text { Phenacetin }^{2} \text { ) }\end{array}$ & $\begin{array}{l}80 \\
71 \\
60 \\
54 \\
81 \\
67\end{array}$ & $\begin{array}{l}2 \\
2 \\
2 \\
2 \\
2 \\
0\end{array}$ & $\begin{array}{l}\text { brown violet } \\
\text { brown violet } \\
\text { brown violet } \\
\text { brown violet } \\
\text { brown violet } \\
\text { fluorescence } \\
\text { quenching }\end{array}$ \\
\hline
\end{tabular}

\footnotetext{
1) $0=U V \quad 1=50 \mathrm{~g} / 1 \mathrm{H}_{2} \mathrm{SO}_{4} \quad 2=$ iodoplatinate

$3=\mathrm{AgNO}_{3} / \mathrm{NH}_{3}$

${ }^{2}$ ) reference standard
}

initially becomes decolorised, then appearing black; all other previously visible spots become decolorised.

The detection limit for morphine and codeine is $0.2 \mathrm{mg} / \mathrm{l}$, for the methaqualone metabolites $1-1.5 \mathrm{mg} / \mathrm{l}$ of urine. Comparable amounts of morphine and codeine were frequently observed simultaneously. The concentrations of morphine in urine found upon hydrolysis were between 1 and $120 \mathrm{mg} / 1(3.5-420 \mu \mathrm{mol} / 1)$ in 29 positive samples, on average between 10 and $50 \mathrm{mg} / 1$ (35$175 \mu \mathrm{mol} / \mathrm{l})$. The detection of traces of morphine together with an excess of codeine is no conclusive proof that morphine has been täken, since codeine is partially metabolized to morphine in the body (5).

This was confirmed in numerous urine samples collected in the morning following intake of $3 \times 30 \mathrm{mg}$ of codeine the day before. The amount of morphine in relation to codeine was about 5-10\%.

\section{Confirmation of methaqualone}

Investigation of the urine of patients receiving treatment with phenothiazine derivates showed that metabolites of methaqualone and phenothiazines developed in ammoniacal eluants are superimposed on the TLC plate (compare detection of methaqualone in 1.c. (11)): In order to exlude false positive results, methaqualone detection is confirmed by TLC in chloroform/acetone (Volumes, $80 \mathrm{ml}+20 \mathrm{ml}$ ) and spraying with Dragendorff's reagent.
In this system only methaqualone and its metabolites migrate, whereas phenothiazines, alkaloids, opiates and 4-aminophenazone remain at the start. As is illustrated in figure 2, a pattern of 4 spots is again obtained, albeit in a different sequence. The sensitivity of detection using Dragendorff's reagent is higher $(0.5 \mathrm{mg} / \mathrm{l}$ of urine) than with iodoplatinate. Thus, following therapeutic doses, 3 to 4 spots are found (compare fig. 2, urine sample C).

Table 2 contains the $R_{\mathbf{s}}$ values of the four metabolite spots $M-m_{3}$ and the frequency distribution thereof. Following hydrolysis two metabolite spots $\left(\mathrm{m}_{1} ; \mathrm{m}_{2}\right)$ can always be detected. The other two spots $\left(\mathrm{M} ; \mathrm{m}_{3}\right)$ are not always present, their detection being dependent on the dose taken and the time at which urine samples are collected. All four spots were invariably detected in cases where overdoses had been taken. The uppermost spot $M$ is still recognizable following the $400 \mathrm{mg}$ therapeutic dose, but is often absent following smaller doses. The other three "metabolites" can still be detected using Dragendorff's reagent 36 hours after the intake of $200 \mathrm{mg}$ of methaqualone.

Two dimensional thin-layer chromatography in the systems chloroform/acetone and chloroform/ethanol/ ammonia or ethyl acetate/methanol/ammonia (Volumes, $85 \mathrm{ml}+10 \mathrm{ml}+5 \mathrm{ml}$ ) and spraying with Dragendorff's reagent and diazotized $p$-nitraniline (16) results in further splitting of the four spots into at least seven spots (compare 1.c. (8)). This means that the pattern of four spots, $M-m_{3}$, contains 4 groups of metabolites. It could also be demonstrated that the metabolite spot $\mathrm{m}_{3}$ appears in the second position from the top in chloroform/ethanol/ammonia solution, and in the fourth position in chloroform/acetone (See Table 2). Following an overdose and collecting urine samples within 24 hours after intake, the intensities of metabolite spots $m_{1}, m_{2}$ and $m_{3}$ were generally in the ratio $2: 3:(0.5-2)$. The change in the distribution of spot intensities occasioned by the altered position enables two characteristic metabolite patterns to be obtained. Methaqualone can be reliably identified by means of these two metabolite configurations.

\section{Detection of methaqualone without hydrolysis}

With a view to mass screening, the question was whether the intake of methaqualone could be detected in urine without hydrolysis (compare 1.c. $(14,15)$ ). Extracts of urines at $\mathrm{pH} 2$ with ether and at $\mathrm{pH} 9$ with dichloromethane/isopropanol (Volumes, $85 \mathrm{ml}+15 \mathrm{ml}$ ) were investigated. Without hydrolysis neither methaqualone nor any metabolites could be detected after a dose of $200 \mathrm{mg}$. Following doses of $400 \mathrm{mg}$ or higher, various spot patterns were obtained. Only in a few cases could all 4 spots be detected, the relation of intensities being quite different from that in hydrolyzed urines. Fre- 


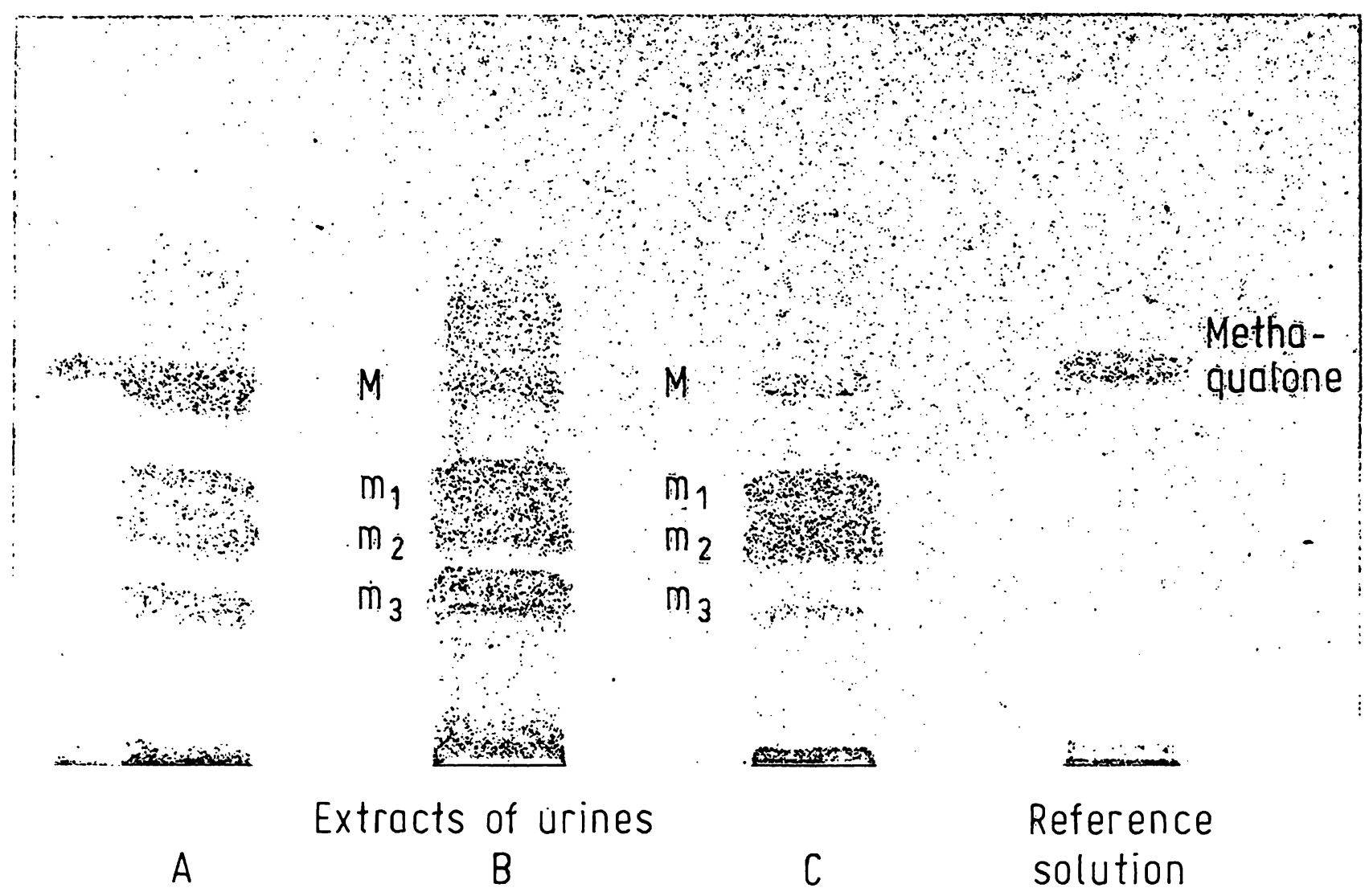

Fig. 2. TLC-screening for drugs in urine.

Detection of methaqualone in urine.

Layer: Precoated TLC-plate silica gel $60 \mathrm{~F}_{254}$.

Solvent: Chloroform/acetone (volumes, $80 \mathrm{ml}+20 \mathrm{ml}$ ).

Detection: Dragendorff reagent.

$M, m_{1}, m_{2}, m_{3}$ methaqualone metabolites.

Methaqualone in $\mathrm{A}$ and $\mathrm{B}$ following ingestion of an overdose, in C following a therapeutic dose of $400 \mathrm{mg}$.

Tab. 2. TLC-screening for drugs in urine

Methaqualone metabolites following hydrolysis of urine

$R_{f}$ values $(\bar{x} \pm 1 S D)$ and frequency

Chloroform/acetone (Volumes, $80 \mathrm{ml}+20 \mathrm{ml}$ )

Chloroform/ethanol/ammonia

(Volumes, $80 \mathrm{ml}+15 \mathrm{ml}+5 \mathrm{ml}$ )

\begin{tabular}{lllll}
$\begin{array}{l}\text { Frequency } N \\
\left(\mathrm{~N}_{\mathbf{0}}=41 \text { samples }\right)\end{array}$ & $\mathrm{R}_{\mathbf{f}} \times 100$ & Substance & $\mathbf{R}_{\mathbf{f}} \times 100$ & $\begin{array}{l}\text { Frequency } \mathrm{N} \\
\left(\mathrm{N}_{\mathbf{0}}=49 \text { samples }\right)\end{array}$ \\
\hline 34 & & $\cdot$ & $80 \pm 3$ & 41 \\
41 & $52 \pm 2,5$ & $\mathrm{M}$ & $60 \pm 4$ & 49 \\
41 & $38 \pm 2,5$ & $\mathrm{~m}_{1}$ & $54 \pm 4$ & 49 \\
40 & $31 \pm 2,5$ & $\mathrm{~m}_{2}$ & $71 \pm 3$ & 45 \\
& $20 \pm 2,5$ & $\mathrm{~m}_{3}$ & $67 \pm 3$ & \\
\hline
\end{tabular}

quently only the "metabolites" $M$ and/or $m_{3}$ are detectable, compare table 3 and 1.c. (14). The concentration of unconjugated metabolites is very small in comparison with that of conjugated metabolites, even in cases of drug intoxication.

\section{Discussion}

Following hydrolysis, phenothiazines and benzodiazepines can be detected with greater certainty, as metabolites excreted in conjugated form are also found. 
Tab. 3. TCL-screening for drugs in urine Mctabolites following methaqualone ingestion. Comparison of spot pattern without hydrolysis and metabolite concentration after hydrolysis of urines.

\begin{tabular}{|c|c|c|c|c|c|}
\hline \multirow[t]{2}{*}{$\begin{array}{l}\text { Sample } \\
\text { Nr. }\end{array}$} & \multicolumn{4}{|c|}{$\begin{array}{l}\left.\text { Intensity }{ }^{b}\right) \text { of metabolite } \\
\text { spots } s^{a)} \text { (Urine not } \\
\text { hydrolyzed) }\end{array}$} & \multirow{2}{*}{$\begin{array}{l}\text { Concentration }{ }^{\mathrm{c})} \text { of total } \\
\text { metabolites in urine (urine } \\
\text { hydrolyzed) } \\
{[\mathrm{mg} / \mathrm{l}]}\end{array}$} \\
\hline & $\mathbf{M}$ & $\mathrm{m}_{1}$ & $\mathrm{~m}_{2}$ & $\mathrm{~m}_{3}$ & \\
\hline $\begin{array}{l}1 \\
2 \\
3 \\
4 \\
5 \\
6 \\
7 \\
8\end{array}$ & $\begin{array}{l}- \\
- \\
- \\
- \\
+ \\
- \\
+ \\
++ \\
++\end{array}$ & $\begin{array}{l}- \\
- \\
- \\
- \\
- \\
- \\
+- \\
+\end{array}$ & $\begin{array}{l}- \\
- \\
- \\
- \\
+ \\
\overline{+} \\
+++e)\end{array}$ & $\begin{array}{l}- \\
+- \\
+- \\
- \\
+- \\
+ \\
++ \\
++\end{array}$ & $\begin{array}{c}30 \\
80^{\text {d) }} \\
130^{\text {d) }} \\
200 \\
250 \\
360 \\
440 \\
590\end{array}$ \\
\hline
\end{tabular}

a) by means of TLC in chloroform/acetone (Volumes, $80 \mathrm{ml}+$ $20 \mathrm{ml})$ and detection with Dragendorff reagent $(\hat{=} 2 \mathrm{ml}$ urine/ spot).

b) - ncgative +- very weak ( $1-2 \mu \mathrm{g} / \mathrm{spot})$ $+\ldots+++$ distinct to very strong.

c) Concentration calculated from the absorbance of the hydrolyzed sample using $A_{1}^{1} \%=1350$ at $235 \mathrm{~nm}$ for all metabolites.

d) Concentration in first urine $10 \mathrm{~h}$ after admittance of $400 \mathrm{mg}$ methaqualone.

c) Intensities possibly artefactual. Urine stored at room temperature for several months before investigation.

Most benzodiazepines can only be detected as a group by their common degradation product 5-chloro-2-aminobenzophenone.

For morphine, the ratio of free and conjugated excreted compounds was determined by comparison with the results obtained by extraction and TLC without hydrolysis of the urine sample. The proportion of morphine excreted unconjugated was between 10 and $100 \%$, in $50 \%$ of all samples it was between 10 and $30 \%$ of the total excretion. In these cases the reliability of the detection is enhanced by hydrolysis of the sample.

Following hydrolysis the ingestion of methaqualone is reliably detected. Even after therapeutic doses three metabolite spots are observed.

Without hydrolysis, however, the detectability of a methaqualone ingestion is not unequivocal. The chromatographic pattern obtained after extraction of 8 urine samples without hydrolysis was compared with the "metabolite" concentrations determined by UV-photometry of the corresponding hydrolysates (See tab. 3). As the main metabolites of methaqualone exhibit very similar absorption coefficients (17), the total concentration of excreted metabolites is determined using $A_{1}^{1 \%} \mathrm{~cm}=1350$ of methaqualone (at $235 \mathrm{~nm}$ ). Following doses of $400 \mathrm{mg}$ of methaqualone, concentrations of 80 and $130 \mathrm{mg} / \mathrm{l}$ were found. The intensity of the only visible spot $\mathrm{m}_{3}$ in the extracts of the unhydrolyzed samples was in the range of the detection limit. corres. ponding to $0.5-1 \mathrm{mg}$ per 1 of urine. Increasing concentrations in the hydrolyzate are not accompanied by a synchronous intensification of the spots in the extracts without hydrolysis. The pattern of all 4 "metabolite" spots can be detected only at concentrations above $400 \mathrm{mg} / \mathrm{l}$. The samples $4-8$ originate from events of intoxication, the dose ingested therein was not known. An intoxication by methaqualone may be detected in some cases without hydrolysis of the urine. Reliable results, however, can only be obtained after performing hydrolysis of the sample.

Other drugs which are also contained in the urine samples do not interfere with the detection of the conjugated compounds.

\section{Conclusion}

The method described has been used in our laboratories in the analysis of several hundred urine samples taken from addicts or people suffering from drug overdose.

Of 250 drug-containing urine samples that we examined in the course of one year, one fifth contained methaqualone. $40 \%$ of these positive samples contained, among other drugs, additional amounts of phenothiazines, diphenhydramine and morphine.

The results were in good agreement with data obtained using more sophisticated, primarily spectroscopic and colorimetric methods.

\section{Acknowledgement}

The authors are indebted Dr. K. H. Beyer and Dr. D. Klinge, Landesanstalt für Lebensmittel-, Arzneimittel und gerichtliche Chemie, Berlin, for supplying urine samples and reference data.

\section{References}

1. Davidow, B., Li Petri, N. \& Quame, B. (1968), Am. J. Clin. Pathol. 50, 714-719.

2. Mulé, S. J. (1969), J. Chromatogr. 39, 302-311.

3. Weissmann, N., Lowe, M. L., Beattie, J. M. \& Demetriou, J. A. (1971), Clin. Chem. 17, 875-881.

4. Hetland, L. B., Knowlton, D. A. \& Couri, D. (1972), Clin. Chim. Acta 36, 473-478.

5. Clarke, E. G. C. (1969), Isolation and identification of drugs, pp. 268, 431, The Pharmaceutical Press, London.

6. Eberhardt, H., Lerbs, O. W. \& Freundt, K. J. (1963), Arzneim. Forsch. 13, 804-805.

7. Beyer, K. H. (1971), Deut. Apoth. Ztg. 111, 1503-1506.

8. Preuß, F. R., Hassler, H. M. \& Köpf, R. (1966), Arzneim. Forsch. 16, 395-401. 
9. Burnett, D., Goudie, J. H. \& Sherriff, J. M. (1969), J. Clin. Pathol. 22, 602-604.

10. Geldmacher-v. Mallinckrodt, M. \& Mang, U. (1970), Z. Klin. Chem. Klin. Biochem. 8, 259-262.

11. Sleeman, H. K., Cella, J. A., Harvey, J. L. \& Beach, D. J. (1975), Clin. Chem. 21, 76-80.

12. Breiter, J. \& Helger, R. (1974), Beitr. Gerichtl. Med. XXXII, 187-189.

13. Breiter, J. \& Helger, R. (1977), Med. Labor. 30, 149-155.

14. Bailey, D. N. \& Jatlow, P. J. (1973), Clin. Chem. 19, 615-620.
15. Berry, D. J. \& Grove, J. (1973), J. Chromatogr. 80, 205-219.

16. Krebs, K. G., Heusser, D. \& Wimmer, H. (1967), in D̈̈̈nnschichtchromatographie, Ein Laboratoriumshandbuch. (Stahl, E. Ed.), 2. Aufl., pp. 829 and 843, Springer-Verlag Berlin, Heidelberg, New York.

17. Arbeitsgruppe Forensische und Toxikologische Chemie der Fachgruppe Lebensmittel- und Gerichtliche Chemie der GdCH (1977), Toxichem Nr. 4.

\section{Dr. J. Breiter}

Biochemische Forschung E. Merck Postfach 4119

D-6100 Darmstadt 